\title{
Improvization as a factor of compository and performance interpretation of modern instrumental music (on the example of "Solo-Solissimo" for violin by K. Tsepkolenko)
}

\author{
Kira Maidenberg-Todorova* \\ Olena Khoroshavina** \\ Inna Hodina*** \\ Olga Voronovskaya**** \\ *Corresponding author, Odessa National Music Academy named after A. V. Nezhdanova, 63, \\ Novoselskogo Str., 65000, Odessa, Ukraine, http://orcid.org/0000-0002-2384-6426, e-Mail: \\ kiraskorp@gmail.com \\ **Odessa National Music Academy named after A. V. Nezhdanova, 63, Novoselskogo Str., 65000, \\ Odessa, Ukraine, orcid.org/0000-0001-9792-0134, e-Mail: elkhguitar@ukr.net \\ ***Odessa National Music Academy named after A. V. Nezhdanova, 63, Novoselskogo Str., 65000, \\ Odessa, Ukraine, orcid.org/0000-0002-8660-1928, e-Mail: innavaltornochki@ukr.net \\ ****South Ukrainian National Pedagogical University named after K. D. Ushynsky, 26, \\ Staroportofrankivska Str., 65000, Odessa, Ukraine, https://orcid.org/0000-0001-7181-9662, \\ e-Mail: o_voron@ukr.net
}

DOI 10.12975/rastmd.20219210 Submitted October 21, 2021 Accepted December 12, 2021

\begin{abstract}
The purpose of the work is to study the mechanisms of formation of the composer's language on the example of modern instrumental music and to determine the relationship between the composer's plan and the interpretive-performing view of the author's text. Interpretiveperforming and comparative analytical approaches in combination with the source method allow identifying the ratio of stable and mobile elements of the author's work, as well as distinguishing between composer's and performer's interpretation of the work. The scientific novelty of the work is the comparative analysis of K. Tsepkolenko's work "Solo-Solissimo №1" for solo violin, as well as the performance versions of this work considered for the first time in the text of the work. The considered performance versions represent two different interpretive approaches to the analyzed work. In Karmella Tsepkolenko's "Solo Solissimo" by Peter Shepard Skaverd, the figure of the performer is felt more than the personality of the composer. This attitude is formed through the free handling of the text in those segments where it is not provided by the author, as well as through the use of their own intonation material at the time of improvisation. Dan Auerbach and Myroslava Kotorovych set the task to convey the author's model of the text, using the composer's intonation material in the improvisational fragment. Thus, improvisation in the considered work is an integral part of the compositional and performing sphere of musical expression. It is thanks to the performer's improvisational skill that the work is filled with content, its genre and style identification from lyrical and philosophical color to dramatic and expressive sphere. The performance of "Solo-solissimo" requires great skill from the violinist, not only technical virtuosity, but also mental, that is required by the author's compositional concept, which is the program basis of the composition. We believe that the intention of this work is, above all, to represent the stylistic competencies of the performer as an unleashed actor-improviser.
\end{abstract}

\section{Keywords}

improvisation, performing interpretation, composer's interpretation, interpretive approach, modern instrumental music 


\section{Introduction}

Modern composer's thinking is characterized by the tendency of "the desire for a clear logical organization of musical space, the rationalization of the creative process, which ultimately determines the dramatic design and expressiveness of the artistic whole. Music at all times creates a special language of communication that knows no equal in openness and breadth of meaningful ingredients, at the same time, the most accurate in terms of psychological processes. The principles of this language are the principles of musical structuring of meaningful reality and giving them a symbolic meaning" (Zavgorodnyaya, 2013, p. 32).

On the other hand, composers try to move away from stable, traditionalcanonical forms, looking not only for new forms of embodiment of creative ideas and new sonorous sonorities, but also new ways of expression, the formation of their own musical thinking. Such a creative field for creating new searches and moving away from any constancy has become improvisation, which exists in different stylistic dimensions, or rather in the interstitial space.

This is the result of a long process of accumulation of meanings of musical language. "The essence of change from one era to another is rooted in the renewal of the subject of music under the influence of new content. Due to this, the direction of evolution is explained, first of all, as a historically regular upward movement along the line from simpler to more complex, i.e., as an increase in the complexity and differentiation of spiritual acts," said Yu. Kholopov (1982).
Namely due to evolutionary development, there is the enrichment of musical language, symbolic expressiveness of musical thinking, which comes to more complex forms, especially in the 21st century, and radically changes not only the way of musical thinking (which, at present, is manifested more in composers and performers, rather than in the listeners), but also the means of organizing the product of such thinking.

Avant-garde composers tried in every way to expand the chronotopic principles of musical composition and give performers maximum interpretive freedom, turn an established work into an independent musical matter, make it a living organism that exists outside the composer's will and self-regulates depending on who touches it.

These processes were laid down in the second half of the 20th - first decade of the 21 st century, when the ratio of stable and mobile elements of the author's musical work acquired a new meaning. An "aleatory-sonorist composition" appeared, in the framework of which a new type of musical theme was selected - "articulatory theme"; there was a rejection of the total stability of the author's text (Maidenberg-Todorova, 2013). 


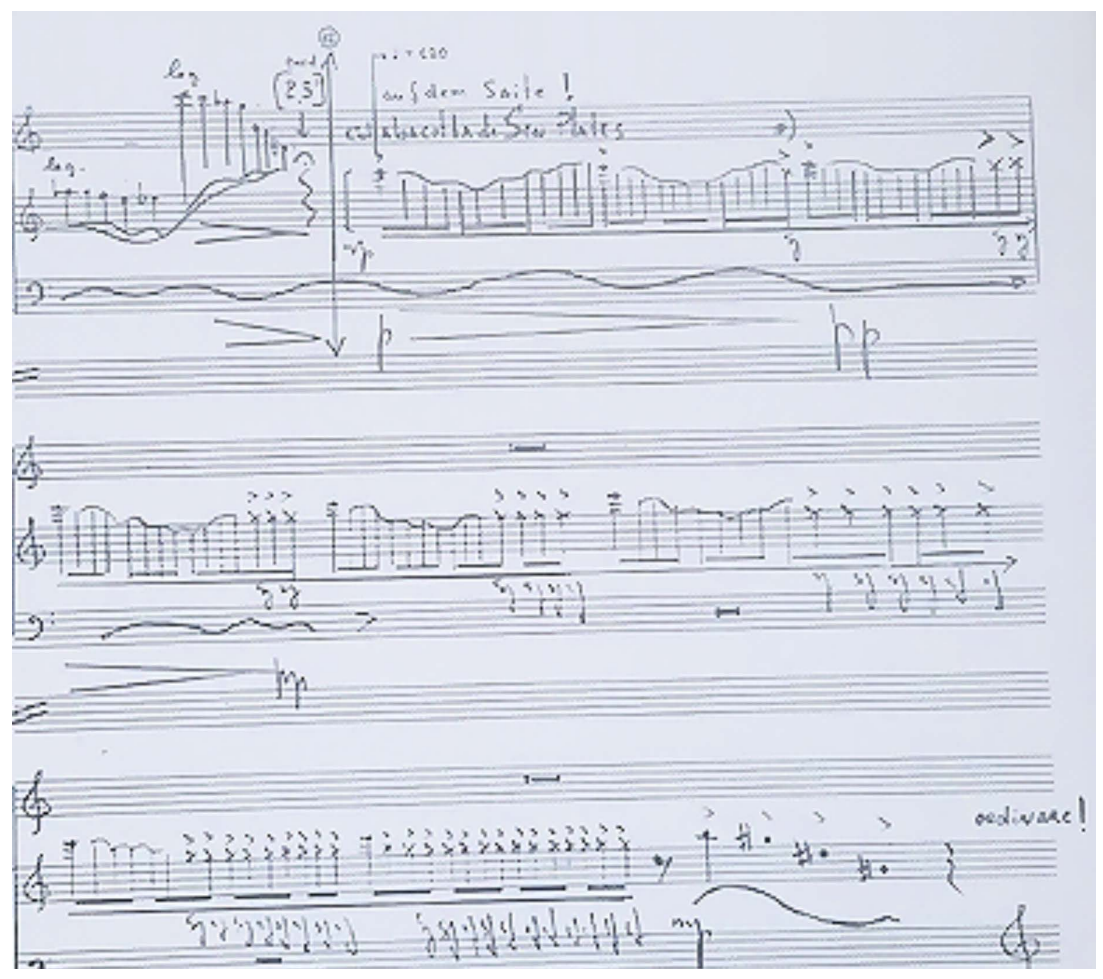

Figure 1. Karmella Tsepkolenko. Duel-duo \#7. Fragment

The desire to create music here and now has led to the abandonment of fixed text and the transformation of the usual musical state into a graphic composition, which can be voiced only by performing improvisation.

Therefore, the relevance of this study is to study the improvisational principles of modern instrumental music in its various different manifestations.

\section{Problem of Study}

The purpose of the work is to study the mechanisms of formation of the composer's language on the example of modern instrumental music and to determine the relationship between the composer's plan and the interpretiveperforming view of the author's text.

The object of this research is contemporary composers' creativity, new methods of implementing composers' creative ideas, and their implementation through performing embodiment.

The subject of this research is improvisation as an independent means of expression, actively used by both composers and performers-interpreters.

\section{Research objectives:}

- To analyze the structure and compositional means of expression "SoloSolissimo" for solo violin K. Tsepkolenko; - To study different versions of the performances of this work;

- To carry out a comparative analysis of the performances of this piece and compare them with the original musical source;

- To reveal the stylistic performers' differences in the reading of this score 
and to determine the attitude of the performers to the improvisational freedom provided to them by the composer;

- By the example of the analyzed interpretations and considered improvisational solutions, designate the figurative and semantic interpretative possibilities of "Solo-Solissimo" for K. Tsepkolenko's solo violin.

\section{Methods}

\section{Research Model}

In frames of research methodology, interpretive-performing and comparative analytical approaches in combination with the source method allow identifying the ratio of stable and mobile elements of the author's work, as well as distinguishing between composer's and performer's interpretation of the work.

In the study, we rely on the theory of interpretation set forth in the works of V. Demyankov, N. Myatieva, P. Riker and A. Samoilenko, which allows us to consider the musical notation text not only as an object of performing, but also of composer's interpretation.

\section{Data Collection Tools-Documents}

The scientific novelty of the work is the comparative analysis of K. Tsepkolenko's work "Solo-Solissimo No.1" for solo violin, as well as the performance versions of this work considered for the first time in the text of the work.

The work, which became the basis for this study, was written by the wellknown Ukrainian composer Karmella Tsepkolenko and is very often performed by violinists around the world. However, this work was still becoming an object of musicological research from the standpoint of the ratio of composer's and performing interpretation.

The selection criterion for performing versions was various audio and video recordings of festival and concert events available to a wide audience.

Below are the details of the performing interpretations at our disposal in chronological order ( Table 1).

Table 1. Performing interpretations

\begin{tabular}{|l|l|l|l|}
\hline Artist name & Country & Date of performance / recording & Recording format \\
\hline Myroslava Kotorovich & Ukraine & February 2021 & Video \\
\hline Dan Auerbach. & USA & 2020 & Video \\
\hline Peter Sheppard Skaerved & Great Britain & January 2021 & Audio \\
\hline Myroslava Kotorovich & Ukraine & September 2021 & Video \\
\hline
\end{tabular}

Each of these performances was analyzed in detail and compared with the author's composer's text. Particular attention was paid to aleatory-sonoristic episodes, that is, such fragments of the text where there is no clear rhythmic or pitch notation, and the performer must show independence in reading.

\section{Findings and Argument}

\section{Theme 1. Features of the author's} score "Solo-Solissimo-1" K. Tsepkolenko.

Improvisation as an independent phenomenon has always been close to 
composer's work. Improvisation is an artistic act in any of its manifestations, which is aimed at the realization of an artistic idea. However, sometimes, even a very technically liberated musician is not able to play without being guided by any musical clues. According to Mikhail Saponov, the mechanism of improvisation "is based on memory, on the skill of playing with memorized traditional elements (Saponov, 1996, p. 76)."The most important principle in the play form is to combine deliberately limited by the choice of thematically equivalent elements (Saponov, 1996, p. 73). That is, the author is inclined to believe that the improvisational process is completely controlled. Michael Epstein defines improvisation as a type of creative activity that "develops between the policies of the known and the unknown, located on different sides of consciousness. Through improvisation as a meeting of two consciousnesses, two unpredictabilities are born. The specificity of improvisation is that it appears as creativity through communication (Epstein, 2008).

Alexander Serdyukov considers improvisation as one of the forms of composition, composing music, which differs in its fundamentally creative nature - the creation of individual meaningful, figurative expression (Serdyukov, 2017). A striking example of the use of improvisation as a means of compositional expression is the work of Karmella Tsepkolenko "Solosolissimo No.1" for solo violin, which was created in 1999. This work has been repeatedly performed by many violinists: Peter Shepard Skaverd (in 1999 and 2021), A. Vlashi (2010), O. Ergieva, G. Savitskaya (2017), Dan Auerbach (2020), Myroslava Kotorovich (2021), and many others.

The composer's interpretation of the work, i.e., the score, contains almost no traditional means of notation. Instead, it has temporal marks, which are expressed in timing (how many seconds a fragment should last), in graphic inserts, which indicate advanced sound production techniques. It is unconventional that the violin part is written on two musical states, which is atypical, but necessary for the composer to convey the sound concept - the violinist not only plays in this work, but also vocalizes certain syllables and sounds, which are marked on the second additional note (Example 1).

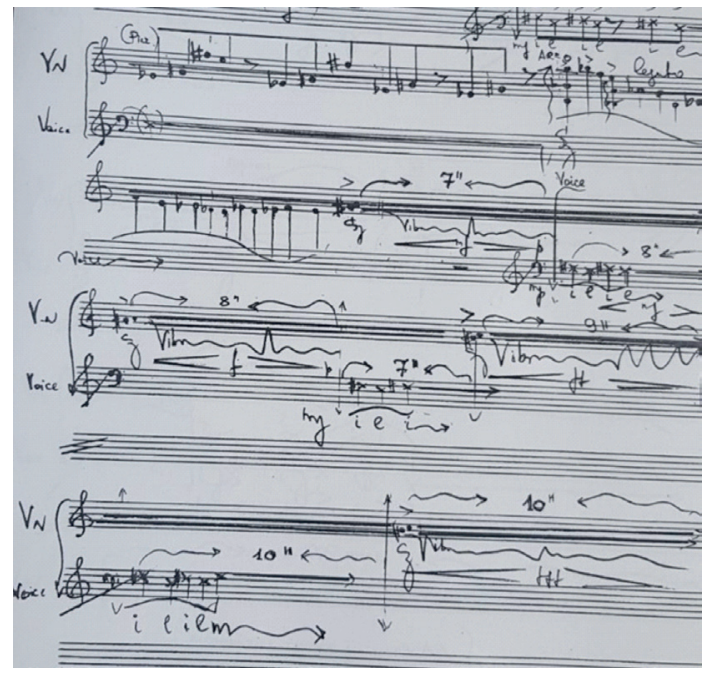

2883
Example 1.

K. Tsepkolenko. "Solo-solissimo" for violin. P.5 
The lack of metric and clear rhythmic instructions is compensated by the almost exact fixed intonation basis of the work. However, the existing tempo instruction at the beginning of the work "Rubato moderato" provides ample opportunities for the performer to improvise the metro-rhythmic side of the work, which makes it multivariate and meaningless.
The score is also full of verbal instructions (Example 2). In particular, the first page of the work is a prevailing mise-en-scène characteristic, an instruction for the performer, who must slowly come out without the instrument previously on the stage, move his lips, play the violin silently before playing the first physical sound.

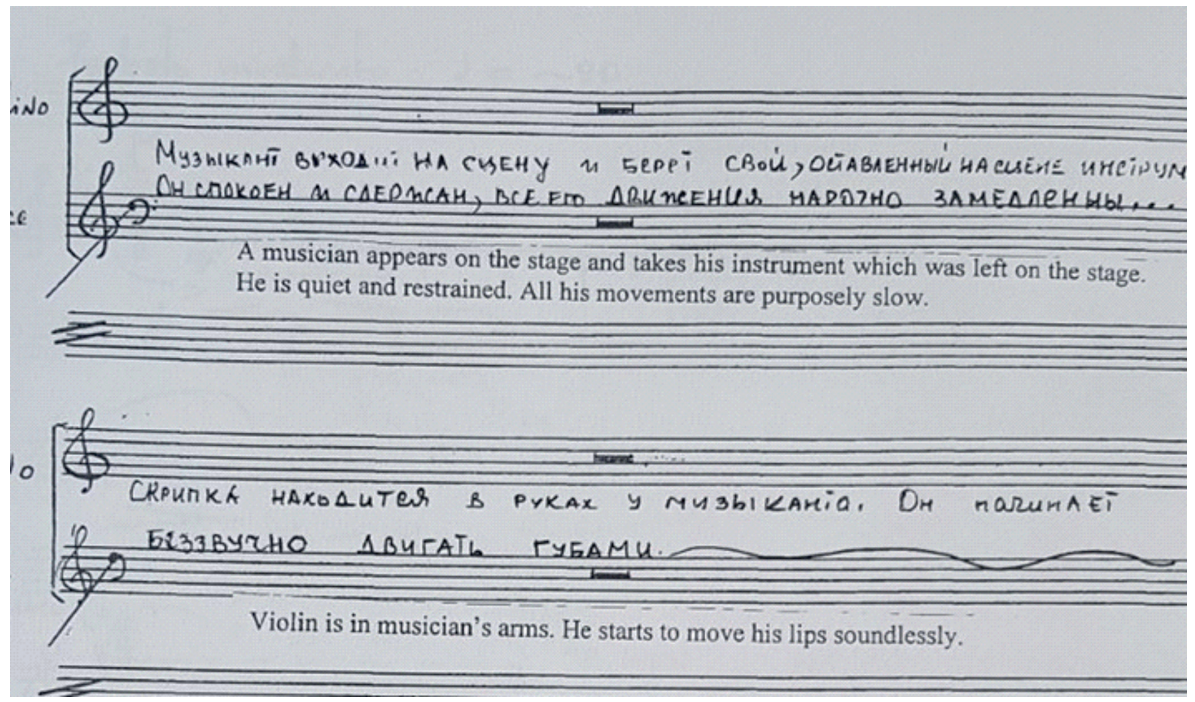

Example 2. K. Tsepkolenko. "Solo-solissimo" for violin. P.1

An important remark of this score is vocals. This fragment is the most the instruction to improvise, using the interesting in terms of performance material of the last page, but without analysis of the work

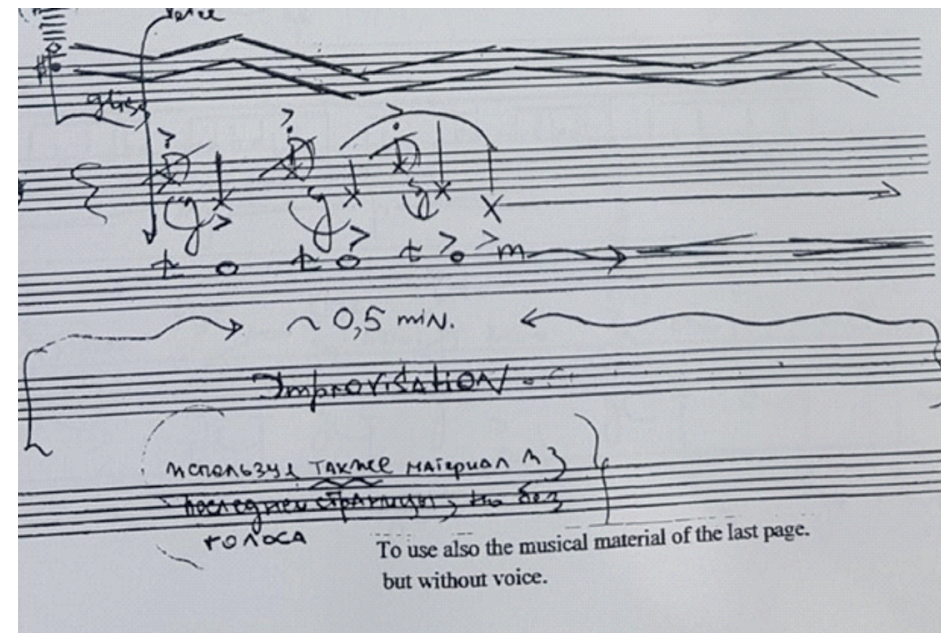

Example 3.K. Tsepkolenko. "Solo-solissimo" for violin. P.6 
Therefore, for musicological and performing analysis, this section is an indicator of the interpretive approach to the author's text, as it most sharply reveals the creative potential of the violinist.

We compared the performance readings of the work by three musicians: Dan Auerbach, Myroslava Kotorovych and Peter Shepard Skaverd. The first two performances were available to us in video, and the third one - in audio recording.

\section{Theme 2. Semantic diversity in performing version of \\ K.Tsepkolenko piece \\ Myroslava Kotorovych and Dan Auerbach versions}

Myroslava Kotorovych ${ }^{1}$ pays great attention to the first page of the text mise-en-scène instructions. She moves very slowly across the stage and injects an acting pause, which she breaks with loud localized exclamations. She devotes almost two minutes to the performative component of the total duration of her performance. The violinist plays the first pages of the work quite emotionally restrained and at a moderate pace. Much attention is paid to the topographic elements of the score - the so-called inaudible structures. On the third and fourth pages in the author's text, there are fast evenly recorded passages. Their character in the performance of the violin also sounds profound. But playful localized inserts contrast with the general character of the instrumental sound, creating a figurative-semantic polyphonic fabric. This is how the fifth and sixth pages of the work are arranged

1. K. Tsepkolenko. "Solo-solissimo-1". Performed by Myroslav Kotorowch. February 2021. https://wnw.youtube.com/ watch?V=y/yOE74h_U
- quite playfully, with a bit of humor. The end of the sixth page of Myroslava Kotorovych reminds of the echo of birds. Next, according to the author's text, the performer must improvise for about 30 seconds. This improvisational phase of the work performed by Myroslava Kotorovych is stylistically sustained; it is almost impossible to separate it from the general sound, it is organically included in the next element of the author's text. But the improvisation is quite short and lasts about 17 seconds. Pages 7-9 are sustained in the same character as the previous ones, but a little compressed in time, so thorough, lighter in sound. The ending of the work looks logical, smooth, gradually fading.

Dan Auerbach ${ }^{2}$, performing this play live at the Two Days and Two Nights of New Music Festival in 2020, also paid close attention to the initial theatrical section. But outside the festival performance (in the considered record) he does not perform this part, starting to play immediately from the second page of the text (although we have a guess that this note may be the fault of the video operator who did not take into account the concept of the work). The violinist plays the first pages overexpressively, with a strong, confident sound. Even pizzicato does not make a contrasting sound. In the same way in this dense sonorous fabric, he weaves vocalization which carries out underlined long. The passage on the fourth page of the work, on the contrary, sounds more frivolous and allegedly between the main text. Then there is a return to continuous sonority and expressive exclamations,

2. K. Tsepkolenko. "Solo-solissimo-1". Performed by Dan Auerbach. https://www.youtube.com/ watch?v=CYwDIOsGdQA 
which the violinist interprets in a unique way - from them, he lengthens at his own discretion, thus emphasizing the emotionality of the musical material. There are almost no silent pauses. The fifth and sixth pages are played on one affect almost continuously, forming the culminating section. The improvisational episode also lasts a short time, about 20 seconds. One should note that Dan Auerbach does not use the material of the last page for improvisation, as recommended by the composer, and the material of the sixth page is glissandi in the upper case, which are very contrasting in the nature of the previous pages of the work. But sometimes this moment of returning to the author's text also looks invisible and happens fairly smoothly, without pausing. The violinist plays a page 7 to 9 a little easier and faster, like an echo, without emphasizing each of the elements of the texture. In recent years, the emotional component is suddenly activated, but this is the end of the work.

\section{Peter Shepard Skaverd's performance}

In the audio performance of Peter Shepard Skaverd ${ }^{3}$, unfortunately, the performative component cannot be reproduced and analyzed through the audio recording format. Another feature of reading the text is interesting. The violinist begins to play from the first rhythmic fragment of the first page of the work. However, instead of verbal exclamations, he uses the sound of a violin whisper, the so-called white noise, which gradually turns into the main part of the work.

\footnotetext{
3. K. Tsepkolenko. "Solo-solissimo-1". Performed by Peter Sheppard Skaerved https://www.youtube.com/ watch?v=-1TFIP6ILhk
}

The violinist interprets the first page of the text freely, the idea is formed that he improvises on a given material, which makes the performance more emotional and expressive. He does not perform voice cues and plays at an accelerated pace, compared to previous interpreters. From the second half of the next page, the violinist accurately performs the author's remarks, sometimes reinforcing the passages with short expressive glissando. The main virtuoso passage in this performance looks like a local culmination - he plays agogically freely and interprets it emphatically emotionally. On 5-6 pages, the violinist also manages to keep the nerve of the work taut. He plays verbal cries confidently and loudly; the violin part is in the background, but the performer does not slow down.

Peter Shepard Skaverd's improvisation is the most original. In his performance, this is the culmination of the work. In terms of timing, this is also the longest improvisational section, lasting a little over a minute. The violinist uses both material similar to the composer's, and his free material, which in some places, in our opinion, stylistically stands out from the composer's text, but does not make this performance less interesting. The most expressive episode is a means of squeezing a bow, to which the performer gradually approaches other expressive searches. On this squeezed sustained sound, he makes a gradual diminuendo and caesura, after which there is a return to the composer's material.

The beginning of the 7th page is played by the violinist very slowly, followed by a gradual acceleration. Then the performer makes a noticeable note in 
the author's text - he does not play a passage on page 8 , which builds an arched structure in the form of the author's text, and immediately goes to the code, perhaps thus deciding to compensate climactic accents transferred to the improvisational part.

\section{Extended version by Myroslava Kotorovych}

It can be useful to understand the interpretative-improvisational aspect of the work by comparing its performances by one violinist in different periods of his activity. Yes, we can compare the performance of "Solo-Solissimo" by K. Tsepkolenko Myroslava Kotorovych, which took place on February 28, 2021 on the Odessa Philharmonic stage, as discussed above, with the recent performance of the same work on September 15, 2021 as part of the festival's posthumous concerts "Two days and two nights" in the hall of the Literary Museum.

Thus, in the performance ${ }^{4}$ of September 15, 2021, in comparison with the previous one, the initial theatrical phase of the work has a more concise form. The violinist does not use verbal exclamations, but leaves only gestures that reproduce the silent play of the violin. Also in terms of duration, the first (outside of music) fragment is much shorter, which is due to the stage space, because the Philharmonic stage needs more time to move on it. The much smaller stage of the hall of the Literary Museum, where the second performance took place, as well as the chamber format of the concert obviously limited the performer in the unfolding of the

4. K. Tsepkolenko. "Solo-solissimo-1". Performed by Myroslav Kotorovych. September 2021. https://www. youtube.com/watch?v=BK44nJqcX24 (30'50 ") theatrical block of the score.

In the further development of the initial phase of the work, in the second performance, there is a greater expressiveness and emotionality, focus on further development than in the previously considered version.

Verbal exclamations that begin at the end of the fourth page of the work and continue on the fifth are sounded differently by the performer. In the first version, Myroslava Kotorovych pronounces them as follows: "yu-eu", in the second - "il-el", from which the playful character previously defined by us is lost, and the sound acquires dramatic firmness.

In the transition from the 5th to the 6th page, in the second performance, the violin softens the tension, and in this part of the work makes a small meaningful caesura-rest. Subsequent sonorous effects on page 6 , by contrast, sound more affirmed and dramatized.

The improvisational episode lasts much longer - about 24 seconds. Interestingly, at the beginning of this section, the violinist, almost "note to note" uses the material of own improvisation from the previous version. The sequence of this block of improvisation is unchanged, but then the improvisational section is supplemented by new sound-sonorous solutions - trills on sul pont., pizz. and vibrated glissando, which are successfully combined to flow into the next section of the work.

Myroslava Kotorovych accelerates the performance of the following compositional material and brings it to 
a climax at the beginning of the eighth page. In the previous performance, this approach was not so emotional, but rather smooth and easy. The final pages also differ in sound. In the second performance, the violinist begins to emphasize the final character of the material much earlier, plays the last vibrated sounds less emotionally, pays more attention to the fading sonority than in the first performance version.

But, taking into account all the differences in tempo deviations, the existing features of improvisational constructions, the duration of the second performance by Myroslava Kotorovych of this work remains the same as the first performance version.

It is interesting to compare the total duration of the analyzed work. The performance of the work by Myroslava Kotorovych in both versions lasts the same 10 minutes 30 seconds, performance by Dan Auerbach - a little more than 6 minutes, and the performance of Peter Shepard Skaverd is 8 minutes 5 seconds.

\section{Conclusion}

Thus, we have two different interpretive approaches to the analyzed work. In Karmella Tsepkolenko's "Solo Solissimo" by Peter Shepard Skaverd, in our opinion, the figure of the performer is felt more than the personality of the composer. First of all, this impression is formed due to the free handling of the text in those segments where it is not provided by the author, as well as due to the fact that Peter Shepard Squaverd uses mainly his performance material for improvisation. Dan Auerbach and Myroslava Kotorovych set the task to convey the author's model of the text, using in the improvisational fragment the composer's intonation material, and each of them places meaningful accents in the work in a completely different way.

After an interpretive analysis, we learned that the work in question was written specifically for Peter Shepard Skaverd, which confirms our initial idea of consciously delegating some of the compositional powers to the performer.

In the analyzed work, improvisational conditions not only allow the performer to open up more creatively on stage, they require from him a much greater degree of creativity and relaxedness, as rationality necessary to preserve the composer's architectonics, emotionality and semantic content. The last component is the most mobile under the influence of the previous factors. As our comparative analysis revealed, each performer sets their own culminating priorities in the production.

Improvisation in the considered work is an integral part of the compositional and performing sphere of musical expression. Namely thanks to the performer's improvisational skill, the work is filled with content, its genre and style identification is from lyrical and philosophical color to dramatic and expressive sphere.

The performance of "Solo-solissimo" requires great skill from the violinist - not only technical virtuosity, but also mental, that is demanded by the author's compositional concept, which is the program basis of the composition. We believe that the vocation of this work is, above all, to represent the stylistic 
competencies of the performer as an unleashed actor-improviser.

\section{Recommendation}

In the future, the study of the functional features of improvisation in a composer's text can be developed in several directions:

- Study of the author's approach of K. Tsepkolenko in the use of improvisational means of expressiveness;

- A study of the work of other contemporary composers who actively use improvisation as an expressive means in their parities;

- On the basis of the studied data, identifying common or different principles for including improvisation in a fixed author's text (both within the framework of one composer's personality, and at the interpersonal level).

\section{Limitations of Study}

At this stage, our proposed research cannot cover all possible existing performing interpretations of the analyzed work. Firstly, this is due to the lack of a number of audio and video recordings in our country. Secondly, at this stage, student and student performances of this work were not taken into account.

Thirdly, this work is often performed, therefore, the material for comparative analysis can be significantly expanded over time. That will deepen our understanding of the interpretative possibilities of this work, to more fully reveal its figurative and semantic plurality.

\section{Acknowledgement}

The authors thanks for Association of new Music in Ukraine and personally composer Karmella Tsepkolenko for agreement and providing music score for researching of this paper. All of the recording material was listened by authors on live performance of festival or concerts, or found on free accesses on Youtube with Comon Creative license.

This paper propose for open accesses. 


\section{Biodata of Authors}

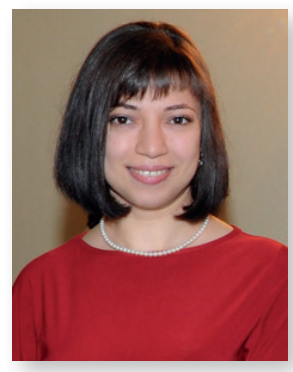

\section{Kira Maidenberg-Todorova}

Ph.D. in Art History, composer, composition teacher. Works at the Odessa National Music Academy named after A.V. Nezhdanova, Department of Music Theory and Composition.

She wrote PhD thesis "Aleatoric-sonoristic composition as an interpretive phenomenon in the context of modern musical poetics".

Associate Professor since 2020.

Member of the National Union of Composers of Ukraine since 2013.

Laureate of the state award named after L. Revutsky (2018).

She has 17 articles and 1 methodical development in two editions. Total articles in the period from 2016 - after the defense of 6 publications, including 1 article in the WOS database, 1 section of the collective monograph, which is part of the SENSE database, 1 methodological development, which is part of the national methodological repository.

Research interests: contemporary composition, improvisation methodology, improvisational music, interpretation of modern music.

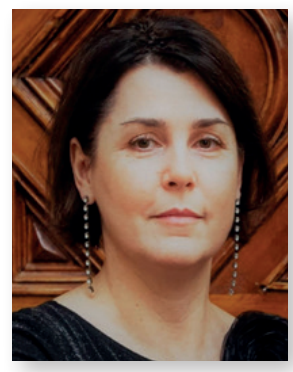

\section{Olena Khoroshavina}

Ph.D. in Art History, guitarist, Founder of the guitar class in Odessa National Music Academy named after A. V. Nezhdanova;

Member of the Presidium of the Association of Guitarists of Ukraine of the National All-Ukrainian Music Union;

Honorary member of the Association of Guitarists of Yugoslavia (Serbia) since 2002;

Author of the project, organizer and art director of the International Youth Festival of Classical Guitar "GuitarSpringFest” since 2004;

Author of the project and organizer - international competition of ensemble performance "Guitar +" 2008;

Author of the project and organizer of the competition of ensemble performance among students of art institutions "Guitar +" in 2010;

Author of the project and the organizer of the open and international competition of guitar performance "in memory of A.K. Vorokhobin “- since 2019;

Founder and chairman of the city public organization "Odessa Guitar Provesin”.

Chairman of the "Odessa Guitar Club" since 2019.

Conducts active pedagogical, social, organizational and executive activities, participates in many international festivals and competitions, as chairman and member of the jury.

Diploma winner of the international competition (Italy, Viareggio 1998), winner of the international competition (Bulgaria, Kyustendil 2012), winner of the international competition as the conductor of the guitar orchestra (Bulgaria, Kyustendil 2012).

Dissertation on the topic "Creative personality of Uros Doichinovych in the context of modern guitar art".

She has 11 articles. Total articles for the period from 2017, after the defense of the dissertation, are in 6 editions.

Research interests: modern school of composition, performing guitar creativity, factors of creative personality in modern guitar art, folklore tendencies and national style in modern guitar creativity. 


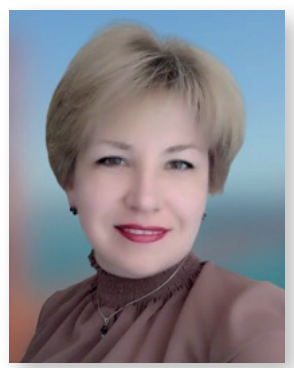

\section{Inna Hodina}

Ph.D. in Art History, musicologist, head of postgraduate and doctoral studies at the Odessa National Academy of Music.

She graduated from the Odessa State Music Academy named after A.V. Nezhdanova. From 2006 to 2009 she studied at the scientific graduate school of the Odessa National Music Academy named after A.V. Nezhdanova.

Since 2010, a teacher of music theory at the Department of Music Theory and Composition. In October 2017, the defense of the PhD thesis "Typology of sonorous intonation in the stylistic poetics of contemporary Ukrainian composers".

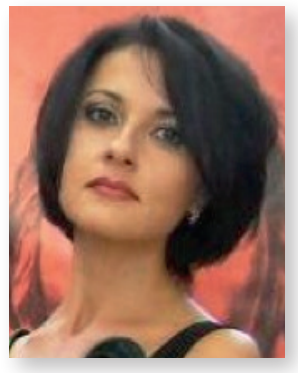

\section{Olga Voronovskaya}

Ph.D. in Art History, musicologist, associate professor of the Department of Music Art and Choreography in South Ukrainian National Pedagogical University named after K.D. Ushinsky, Associate Professor of History of Music and Musical Ethnography in Odessa State Music Academy named after A.V. Nezhdanova.

In 2005 she defended her dissertation on "Musical motor skills as a category of musicology."

Publications: 32 publications, including 1 article in the foreign publication "Journal of History Culture and Art Research", which is part of the Web of Science.

Research interests: category and phenomenon of musical movement; methodological and methodical bases of modernization of professional training of teachers of art disciplines. 
Notes

1. K. Tsepkolenko. "Solo-solissimo-1". Performed by Myroslav Kotorovych. February 2021. https://www.youtube.com/ watch?v=y7lyOE74h_U

2. K. Tsepkolenko. "Solo-solissimo-1". Performed by Dan Auerbach. https: //www. youtube. $\mathrm{com} /$ watch? $v=\mathrm{CYwDIOsGdQA}$

3. K. Tsepkolenko. "Solo-solissimo-1". Performed by Peter Sheppard Skaerved https: / / www. youtube. com / watch?v=1TFIP6lLhk

4. K. Tsepkolenko. "Solo-solissimo-1". Performed by Myroslav Kotorovych. September 2021. https://www.youtube. com/watch?v=BK44nJqcX24 (30’50")

\section{References}

Benson, B. E. (2003). The improvisation of musical dialogue: A phenomenology of music. Cambridge University Press.

Demyankov, V. (1989). Interpretation, understanding and linguistic aspects of their computer modeling. Moscow.: Publishing House of Moscow University,

Epstein, M. (2008). Collective improvisation: creativity through communication. Part two. Topos theory. Literary and Philosophical Journal. http://www.topos.ru/article/6530

Kholopov, Y. (1982). Changing and unchanging in the evolution of musical thinking. Problems of Tradition and Innovation in Contemporary Music. Moscow: Soviet Composer. http:// www.kholopov.ru/izm/

MacDonald, R., Wilson, G., \& Miell, D. (2012). Improvisation as a creative process within contemporary music. Musical imaginations:
Multidisciplinary perspectives on creativity, performance and perception, 242-255.

Maidenberg-Todorova, K.I. (2013). Composer and performing interpretative properties of aleatory-sonoristic composition. Art and Education, 5, 32-41.

Myatieva, N. (2010). Performing interpretation of music of the second half of the twentieth century: questions of theory and practice. Dissertation of $\mathrm{PhD}$ in arts. 17.00.02. Magnitogorsk, 2010.

Peters, G. (2009). The philosophy of improvisation. Chicago. : The University of Chicago Press.

Ricoeur, P.(1974) Conflict of interpretations. Essays on hermeneutics Northwestern University Press.

Samoilenko, 0 (2011). Theory of musicological interpretation as a direction of modern hermeneutics. Journal of the National Academy of Music. PI Tchaikovsky: scientific journal. Kyiv: NMAU named after PI Tchaikovsky - № 2 (11), 3-10

Saponov, M. (1996). Minstrels. Essays on the Musical Culture of the Western Middle Ages. Moscow: Prest.

Serdyukov, A. (2017). Traditions of improvisation in modern academic musical culture. Dissertation of PhD in arts. 17.00.02. Rostov on Don.

Zavgorodnyaya, G. (2013). Polyphony as a fundamental basis of musical thinking: to the methodology of musicological analysis: dissertation, PhD in arts. 17.00.03: Musical art. Kiev. 